\title{
A new species of Wellsopsyllus (Copepoda, Harpacticoida, Paramesochridae) from the deep Southern Ocean and remarks on its biogeography
}

\author{
Johanna Kottmann • Terue Cristina Kihara • \\ Thomas Glatzel • Gritta Veit-Köhler
}

Received: 17 August 2011/Revised: 7 March 2012/ Accepted: 26 March 2012/Published online: 15 April 2012

(C) Springer-Verlag and AWI 2012

\begin{abstract}
The new deep-sea copepod species of the family Paramesochridae (Copepoda, Harpacticoida) presented here was collected during the scientific ANtarctic benthic DEEP-sea biodiversity cruise II (ANDEEP II) to the Weddell Abyssal Plain and western Weddell Sea and the CROZet natural iron bloom and EXport experiment (CROZEX cruise) to the Crozet Isles in the Indian Ocean. The new species has been allocated to the subgenus Wellsopsyllus within the genus Wellsopsyllus Kunz, 1981, based on the 1-segmented endopods and 3-segmented exopods of swimming legs 2-4. Furthermore, the new species shows a 1-segmented exopod of the antenna. Wellsopsyllus (W.) antarcticus sp. n. can be distinguished from its congeners by its small body size, the presence of two setae on the distal segment of the endopod of the first swimming leg, by the very small furcal rami, the extremely reduced endopods of second and third swimming legs, the reduced mandibular palp and maxillula, as well as by the size and armature of the fifth and sixth swimming legs in both sexes. Difficulties of the placement of the new species into a suitable genus show an insufficiency in the present family classification. In the future, a revision of the genus
\end{abstract}

Communicated by Heinz-Dieter Franke.

J. Kottmann · T. C. Kihara · G. Veit-Köhler $(\bowtie)$

Senckenberg am Meer,

DZMB - German Centre for Marine Biodiversity Research,

Südstrand 44, 26382 Wilhelmshaven, Germany

e-mail: gveit-koehler@senckenberg.de

J. Kottmann · T. Glatzel

Biodiversity and Evolution,

Department of Biology and Environmental Science,

Carl von Ossietzky University Oldenburg,

26111 Oldenburg, Germany
Wellsopsyllus is essential. With its presence in the western Weddell Sea and the Indian Ocean, the new species may have a wide distribution range. Furthermore, it is the first abyssal species of the genus Wellsopsyllus sampled outside of the Scotia Sea.

Keywords Meiofauna - Meiobenthic copepods . Species description - ANDEEP II · CROZEX · Systematics - Distribution range

\section{Introduction}

Increased attention on the study of the diversity and biogeography of benthic deep-sea copepods has been witnessed during the last few years (Gheerardyn and Veit-Köhler 2009; Menzel 2011; Menzel et al. 2011). Nevertheless, only 10 species of the harpacticoid family Paramesochridae have been described from depths below 200 m until now (Becker 1979; Drzycimski 1967; Lang 1936, 1948; Plum and George 2009; Vasconcelos et al. 2009; Veit-Köhler 2004, 2005; Veit-Köhler and Drewes 2009). This can be due to the low number of systematists working on this harpacticoid family [e.g., 16 new species collected from Southeastern Atlantic abyssal plains and the deep Southern Ocean in the period 2000-2005 (Gheerardyn and Veit-Köhler 2009) remained undescribed]. International scientific programs, like the "Census of Marine Life" (CoML), provide the possibility to extend the present knowledge of deep-sea copepods and to describe new species such as Wellsopsyllus (Wellsopsyllus) antarcticus sp. $\mathrm{n}$.

The specimens presented herein were collected during the RV Polarstern ANDEEP II cruise and the RRS Discovery CROZEX cruise (Fig. 1, stations and collected 


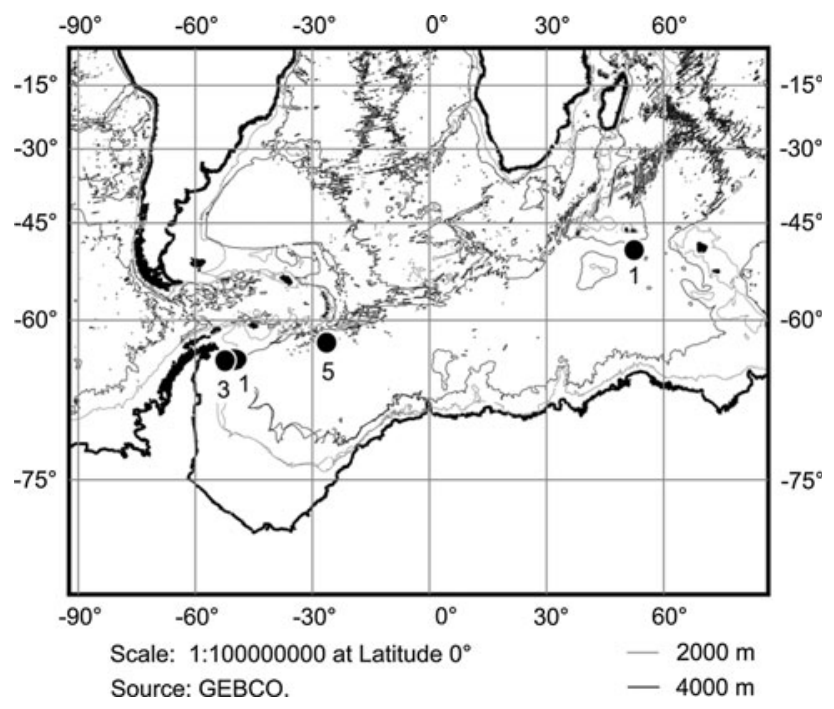

Fig. 1 Geographic distribution of Wellsopsyllus (W.) antarcticus sp. n. (black dots) collected from the Weddell Sea and the Indian Ocean during the ANDEEP II and Benthic CROZEX expeditions. Next to each symbol, the number of specimens found per station is given. Station numbers from west to east: PS61/133, PS61/132, PS61/138, 15775 M6 C9

individual numbers indicated). These expeditions were part of the 10-year program for the study of abyssal plains, the "Census of the Diversity of Abyssal Marine Life" (CeDAMar), a field project within the CoML framework (Martínez Arbizu and Brix 2008).

The first two legs of the ANtarctic benthic DEEP-sea biodiversity program (ANDEEP) took place in 2002. Until then, the deep-sea fauna of the Southern Ocean remained unexplored, and this program provided the first comprehensive survey of micro-, meio-, macro- and megafaunal communities of the deep Scotia and Weddell Seas (e.g., Brandt et al. 2004; Gutzmann et al. 2004). Emertonia andeep (Veit-Köhler, 2004) was the first species of Paramesochridae described from the ANDEEP material. Later, the species Emertonia diva (Veit-Köhler, 2005) described from the Angola Basin was detected in the ANDEEP samples (Gheerardyn and Veit-Köhler 2009).

The CROZet natural iron bloom and EXport experiment (CROZEX) explored the area around the Crozet Isles in the southern part of the Indian Ocean (Pollard et al. 2007). The benthic part of the program was carried out in 2005/2006 and investigated the variation of two abyssal sites ( $\sim 4,200 \mathrm{~m}$ deep) in terms of the reaction of benthic ecosystems to different productivity regimes (Wolff et al. 2011). One site was located east of the Crozet Isles beneath an area where an enduring seasonal phytoplankton bloom was observed. The second site was an oligotrophic "High Nutrient Low Chlorophyll" (HNLC) region south of the Crozet Isles (Wolff et al. 2011).
Members of the family Paramesochridae Lang, 1944 like the majority of the benthic harpacticoid copepods belong to the meiofauna size class (animals passing a 1-mm sieve and being retained on a $32-\mu \mathrm{m}$ sieve). They are interstitial animals with a cylindrical body shape (Fig. 2) typically inhabiting intertidal and shallow-water sandy sediments. To date, 14 species belonging to the genus Wellsopsyllus have been described (including 1 species incertae sedis). Twelve of these species seem to be restricted to shallowwater areas. Only two deep-sea species were known until now, namely Wellsopsyllus (W.) abyssalis (Becker, 1979) and Wellsopsyllus (I.) antoniae (Plum and George, 2009).

\section{Materials and methods}

The sediment samples of two scientific deep-sea cruises were investigated. On board of RV Polarstern samples were taken along the Scotia Arc and in the northern Weddell Sea during ANDEEP II (expedition no. ANT XIX/4, 02/28/-04/01/2002). The RRS Discovery Cruise 300 CROZEX (12/01/2005-01/14/2006) lead to the Crozet Isles in the southwestern area of the Indian Ocean (Fig. 1). Sediment samples were taken with a multicorer (MUC). More information about the sampling sites is summarized in Table 1. Details on sampling strategy and sample treatment are described by Veit-Köhler (2004).

Meiofauna was sorted to higher taxon level, and copepods were subsequently transferred to glycerin. Specimens of Wellsopsyllus (W.) antarcticus sp. n. were sorted with the aid of a Leica MZ 12.5 stereomicroscope. The female holotype and the male paratype (allotype) were drawn from the dorsal and lateral side. Detailed drawings of several body parts were made using undissected specimens, as the animals are very small and the position of mouthparts and reduced swimming legs allows a thorough observation. The dissected parts of the paratypes were mounted on slides with glycerin. Drawings were made with the aid of a drawing tube on a Leica DM 2500 microscope equipped with differential interference contrast (DIC) at 400-2000 $\times$ magnification.

The male paratype of Wellsopsyllus (W.) antarcticus sp. n. was scanned with a confocal laser scanning microscope (Fig. 2). Specimens were stained with saturated aqueous solution of acid fuchsin with water (modified after Michels and Büntzow 2010) and viewed on a Leica TCS SP5 equipped with a Leica DM 5000 B microscope $(640 \times$ magnification) and three visible light lasers. Based on the image stacks, maximum intensity projections were created with the Leica LAS software (Leica Microsystems). The final images were assembled and adjusted for contrast and brightness using the software Adobe Photoshop CS4. Scale bars in figures are indicated in millimeters [mm]. 


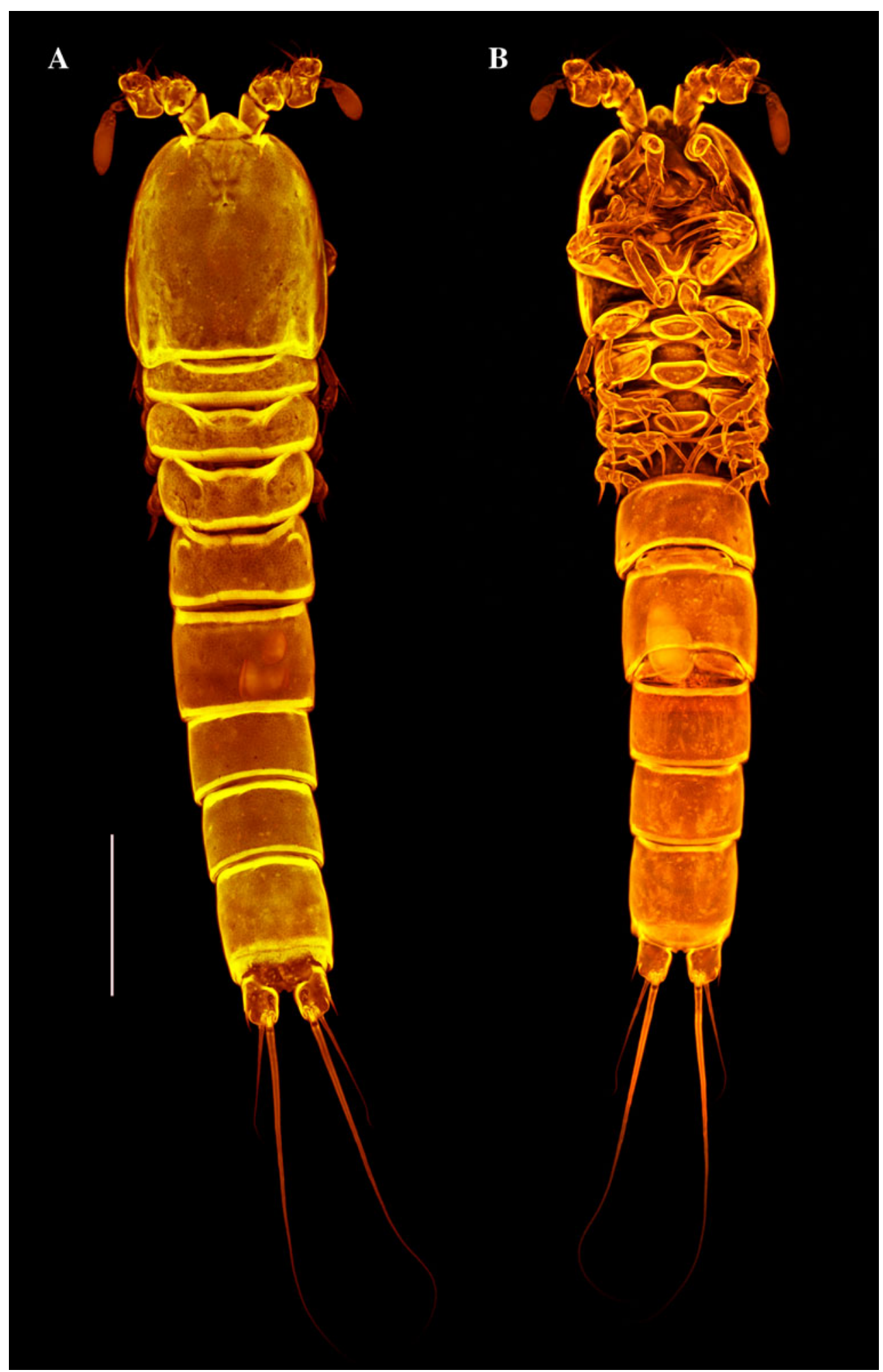

Fig. 2 CLSM picture of Wellsopsyllus (W.) antarcticus sp. n., male paratype 1 (allotype). a Habitus, dorsal view; b habitus, ventral view; scale bar $=0.05 \mathrm{~mm}$

The following abbreviations are used in the text: $\exp (\mathrm{s})=\operatorname{exopod}(\mathrm{s}), \quad \operatorname{enp}(\mathrm{s})=\operatorname{endopod}(\mathrm{s})$, aes $=$ aesthetasc, benp $=$ baseoendopod, $\mathrm{P} 1-\mathrm{P} 6=$ swimming legs
1-6; examples: "enp1" = the first segment of the endopod, "enp1 P2" = the first segment of the endopod of P2. 
Table 1 Station information for the ANDEEP II and CROZEX cruises: station number (consisting of cruise no., station no., deployment no.), sampling date, geographic position, water depth, total number of processed meiofauna cores and number of collected individuals of Wellsopsyllus (W.) antarcticus sp. n. (males and females indicated)

\begin{tabular}{|c|c|c|c|c|c|c|c|}
\hline \multirow[t]{2}{*}{ Expedition } & \multirow[t]{2}{*}{ Station no. } & \multirow[t]{2}{*}{ Sampling date } & \multicolumn{2}{|l|}{ Coordinates } & \multirow{2}{*}{$\begin{array}{l}\text { Depth } \\
\text { (m) }\end{array}$} & \multirow{2}{*}{$\begin{array}{l}\text { Total number of } \\
\text { meiofauna cores }\end{array}$} & \multirow{2}{*}{$\begin{array}{l}\text { Number of Wellsopsyllus } \\
\text { (W.) antarcticus sp. n. }\end{array}$} \\
\hline & & & Latitude & Longitude & & & \\
\hline ANDEEP II & PS61/132-5 & 03/07/2002 & $65^{\circ} 17.68^{\prime} S$ & $53^{\circ} 23.00^{\prime} \mathrm{W}$ & 1,978 & 3 & 1 우 \\
\hline \multirow[t]{5}{*}{ Weddell Sea } & PS61/133-8 & 03/07/2002 & $65^{\circ} 20.09^{\prime} \mathrm{S}$ & $54^{\circ} 14.72^{\prime} \mathrm{W}$ & 1,107 & 3 & $1 ㅇ ㅜ 1 \hat{0}$ \\
\hline & PS61/133-10 & 03/07/2022 & $65^{\circ} 20.30^{\prime} \mathrm{S}$ & $54^{\circ} 14.67^{\prime} \mathrm{W}$ & 1,109 & 2 & $1 \hat{\sigma}$ \\
\hline & PS61/138-3 & $03 / 17 / 2002$ & $62^{\circ} 57.70^{\prime} \mathrm{S}$ & $27^{\circ} 53.63^{\prime} \mathrm{W}$ & 4,538 & 6 & $1 \hat{\sigma}$ \\
\hline & PS61/138-5 & $03 / 17 / 2002$ & $62^{\circ} 57.82^{\prime} \mathrm{S}$ & $27^{\circ} 54.01^{\prime} \mathrm{W}$ & 4,540 & 6 & 1 우 $1 \hat{\jmath}$ \\
\hline & PS61/138-11 & $03 / 18 / 2002$ & $62^{\circ} 58.03^{\prime} \mathrm{S}$ & $27^{\circ} 54.08^{\prime} \mathrm{W}$ & 4,541 & 6 & $1 ㅇ ㅜ 1 \hat{0}$ \\
\hline $\begin{array}{l}\text { CROZEX } \\
\text { Indian Ocean }\end{array}$ & 15775 M6 C9 \#3 & $12 / 27 / 2005$ & $49^{\circ} 03.65^{\prime} \mathrm{S}$ & $51^{\circ} 14.21^{\prime} \mathrm{E}$ & 4,202 & 1 & $1 \hat{\jmath}$ \\
\hline
\end{tabular}

The map was created using PanMap, a tool provided by the PANGAEA Publishing Network for Geoscientific and Environmental Data (Diepenbroek et al. 2000). General bathymetric charts were added from IOC, IHO and BDOC (1994) and vector shorelines from NGDC/NOAA (1993).

\section{Results}

Systematics

Order Harpacticoida Sars, 1903.

Family Paramesochridae Lang, 1944.

Subfamily Paramesochrinae Huys, 1987.

Genus Wellsopsyllus (Wellsopsyllus) Kunz, 1981.

Wellsopsyllus (Wellsopsyllus) antarcticus Kottmann \& Veit-Köhler sp. n.

\section{Material}

Sediment samples of three stations of the ANDEEP II expedition contained specimens of the new species (PS61/ 132, 1,978 m depth; PS61/133, 1,107-1,109 m depth; PS61/138, 4,538-4,541 m depth; MUC core sampled surface $25.5 \mathrm{~cm}^{2}$, upper $10 \mathrm{~cm}$ of the sediment). The single specimen collected during the CROZEX expedition was sampled at station 15775 M6 C9 \#3 (4,202 m depth; Megacorer sampled surface $78.5 \mathrm{~cm}^{2}$, upper $5 \mathrm{~cm}$ of the sediment; Fig. 1; Table 1). The examined specimens were registered and deposited in the collection of the Senckenberg Forschungsinstitut und Naturmuseum Frankfurt am Main (SMF), Germany (full details in the SeSam online database sesam.senckenberg.de; Brandis et al. 2007).

Station numbers contain the following information "expedition no./station no._- gear deployment no.—core no.”.
Female holotype, SMF (37035): dissected adult female, mounted on 7 slides; station no. PS61/138-5-3, 03/17/2002, $62^{\circ} 57.82^{\prime} \mathrm{S}, 27^{\circ} 54.01 \mathrm{~W}$, depth 4,540 m.

Male paratype 1 (allotype), SMF (37036): adult male, not dissected, 1 slide; station no. PS61/138-3-1, 03/17/ $2002,62^{\circ} 57.70^{\prime} \mathrm{S}, 27^{\circ} 53.63^{\prime} \mathrm{W}$, depth $4,538 \mathrm{~m}$.

Female paratype 2, SMF (37037): adult female, not dissected, 1 slide; station no. PS61/138-11-5, 03/18/2002, $62^{\circ} 58.03^{\prime} \mathrm{S}, 27^{\circ} 54.08^{\prime} \mathrm{W}$, depth $4,541 \mathrm{~m}$.

Female paratype 3, SMF (37038): dissected adult female, mounted on 6 slides; station no. PS61/133-8-A, $03 / 07 / 2002,65^{\circ} 20.09^{\prime} \mathrm{S}, 54^{\circ} 14.72^{\prime} \mathrm{W}$, depth $1,107 \mathrm{~m}$.

Type locality

Type locality is station PS61/138 $\left(62^{\circ} \mathrm{S}, 27^{\circ} \mathrm{W}\right)$ in the Weddell Abyssal Plain.

Etymology

The species name antarcticus refers to the deep sea near Antarctica, where the species was found.

Description

\section{Female holotype}

Habitus (Fig. 3a, b). Total body length measured from anterior tip of rostrum to posterior margin of telson: holotype, $0.325 \mathrm{~mm}$, paratype $2,0.317 \mathrm{~mm}$; including the furcal rami: holotype, $0.349 \mathrm{~mm}$, paratype 2, $0.334 \mathrm{~mm}$.

Body cylindrical, slightly depressed dorsoventrally, with prosome only slightly wider than urosome. Whole body covered with small, round depressions resembling the surface of a golf ball (see also Fig. 2). Pores and sensilla distributed dorsally and laterally on cephalothorax and free 
Fig. 3 Wellsopsyllus (W.) antarcticus sp. n., female holotype. a Habitus, dorsal view; b habitus, lateral view. Scale bar $=0.1 \mathrm{~mm}$

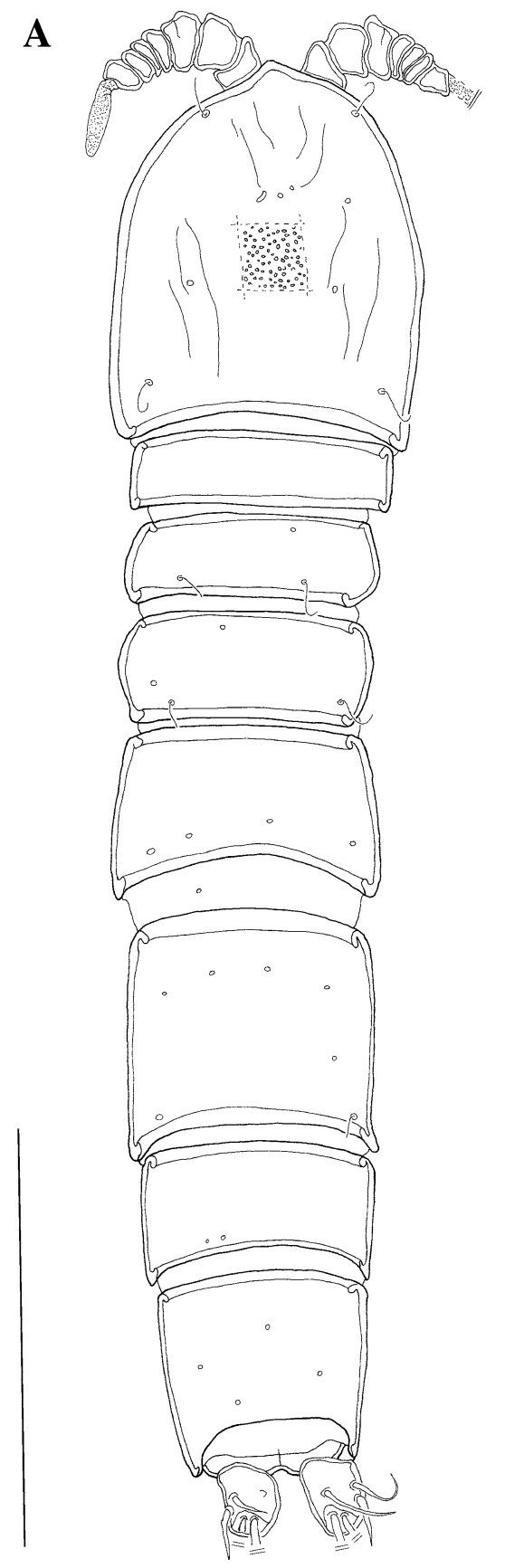

B

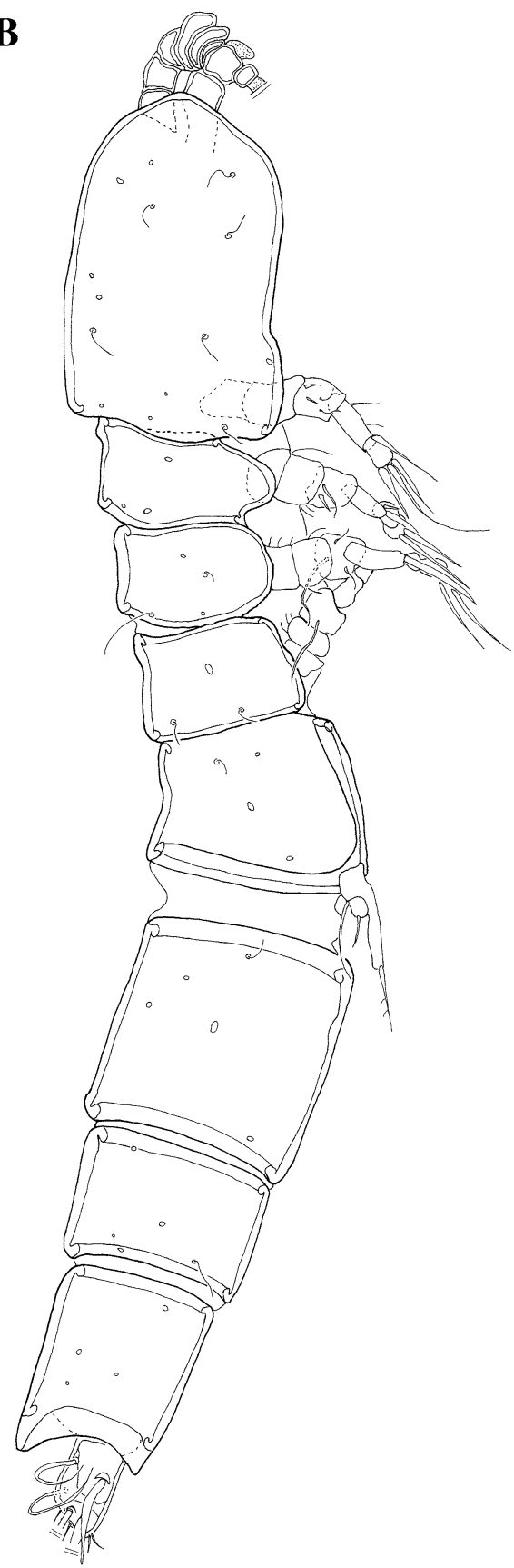

body somites. Furcal rami of adult female (Fig. 4b) short and cylindrical, as long as wide, with 5 setae and several small spinules along inner and terminal margin. Seta I absent; seta II slender, dorsally displaced; seta III slender, situated dorsolaterally; seta IV and V dorsally displaced (broken in female holotype), in paratypes (checked before dissection) long and slender; seta IV spinulose along the outer margin; seta V twice as long as seta IV, with minute spinules at the end of the proximal third; seta VI absent; seta VII slender, plumose, on inner dorsal surface of furcal rami.
Rostrum (Fig. 3). Small, hyaline, fused to cephalothorax with no visible sensilla.

Antennule (Fig. 5). Eight-segmented, segment I with row of long inner spinules. Armature formula: I (1): 1 slender naked seta; II (6): 2 pinnate setae, one of which is long, 4 slender naked setae, one of which is long; III (6): 6 slender naked setae, two of which are small; IV $(2+$ $(1+$ aes)): 2 slender naked setae and 1 long slender seta (the latter fused at base with aesthetasc); V (1): 1 long slender naked seta; VI (0); VII (3): 3 slender naked setae; VIII $(7+(1+$ aes $)): 2$ long pinnate setae, 6 slender naked 
Fig. 4 Wellsopsyllus (W.) antarcticus sp. n. a Male furcal rami [paratype 1 (allotype)]; b female furcal rami (holotype). Scale bar $=0.05 \mathrm{~mm}$

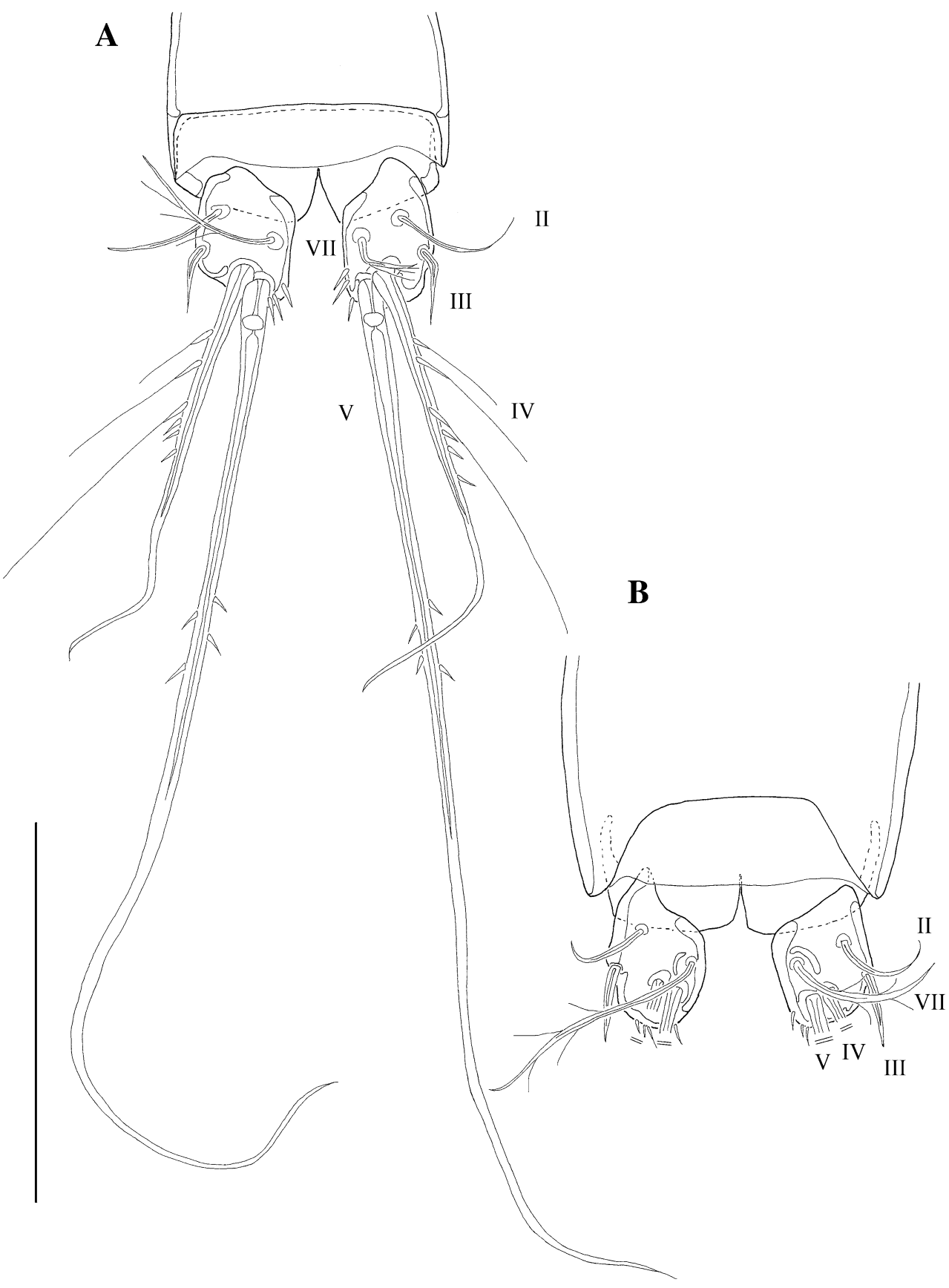

slender naked setae. Mandibular palp uniramous. Basis with a row of spinules. Enp 2-segmented: first segment with 1 very short inner seta, second segment with 1 inner proximal, unipinnate, stout seta and 4 apical naked slender setae, one of which is short. Exp absent.

Maxillula (Fig. 6c, d). Praecoxal arthrite [Fig. 6d (drawn from the posterior view)] with 1 outer slender naked seta. Distal margin with 6 teeth fused at base with the arthrite, 5 of which are strong, stout (one of which is unipinnate) and 1 slender tooth; 3 of the teeth carry 1 small spinule. Coxal endite bearing 1 plumose and stout, and 1 slender naked seta. Basal endite armed subapically 
Fig. 5 Wellsopsyllus (W.) antarcticus sp. n., female antennula (paratype 2). a Segmentation; b single segments with setation. Scale bar $=0.02 \mathrm{~mm}$

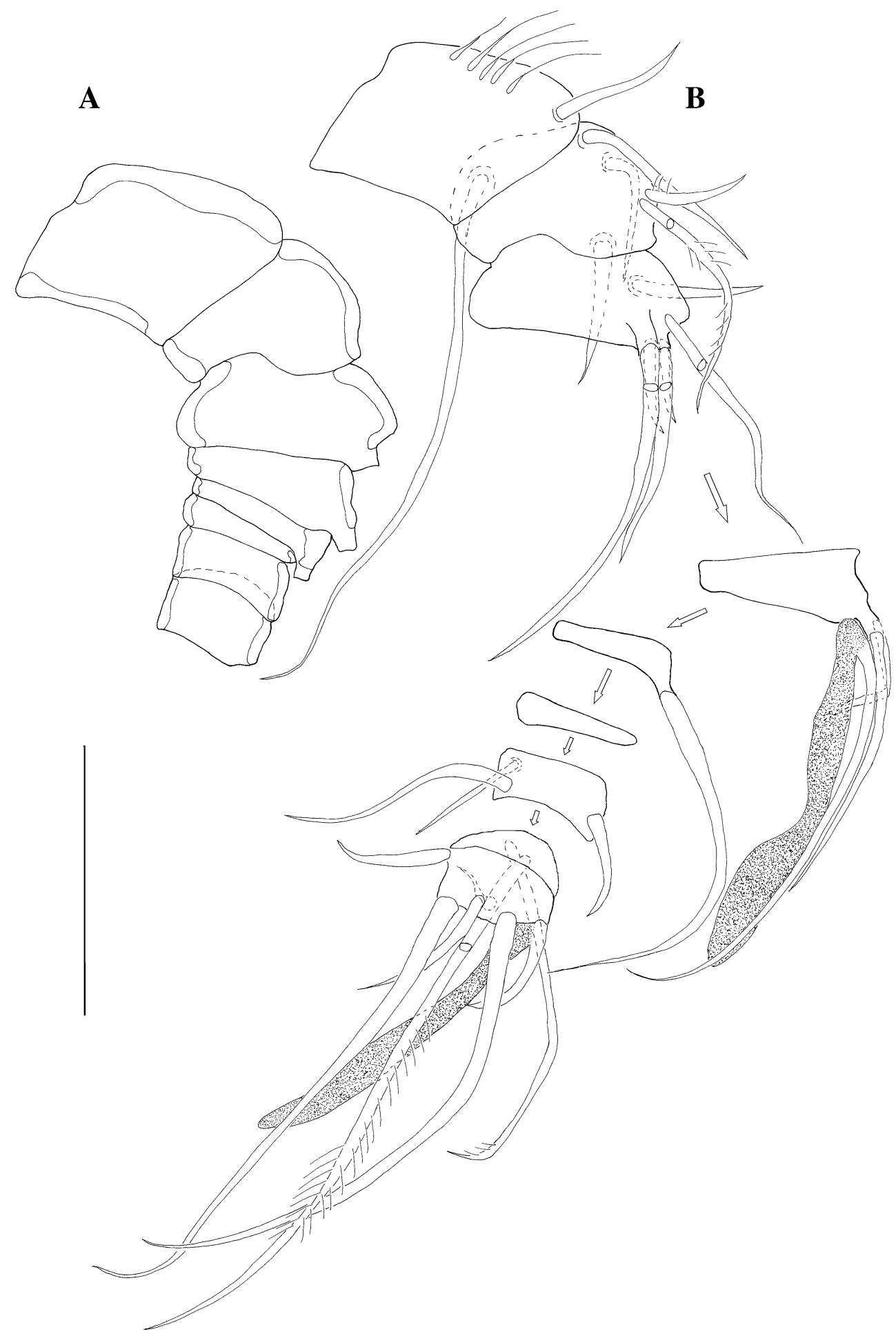

with 1 slender naked and 1 slender unipinnate seta, and apically with 7 slender setae, two of which are unipinnate. Without exp and enp (absent in all available specimens). There is, however, 1 small depression laterally.

Maxilla (Fig. 6e). Syncoxa with three endites. Proximal endite slightly bilobed, armed with 3 strong setae, one of which is spinulose. Middle endite with 2 strong setae, one of which is spinulose. Distal endite with 1 spinule laterally and 2 apical strong setal elements, one of which is spinulose. Syncoxa and basis seemingly fused. Basis with one stout plumose claw and 1 short slender naked accompanying seta. Enp 1-segmented, apically with 1 stout plumose claw, 1 long slender naked seta and 3 subapical slender 
Fig. 6 Wellsopsyllus (W.) antarcticus sp. n., female. a Antenna (paratype 2);

b antennary exopod in posterior view (paratype 2); c maxillula, arrow indicates depression (no endopod or exopod detected), outer seta of praecoxal arthrite marked with asterisk (paratype 3); d praecoxal arthrite of maxillula in posterior view, outer seta of praecoxal arthrite marked with asterisk (paratype 3); e maxilla (paratype 2); f mandible (paratype 3); g mandibular palp (holotype); $\mathbf{h}$ maxilliped (paratype 2). Scale bar $=0.02 \mathrm{~mm}$

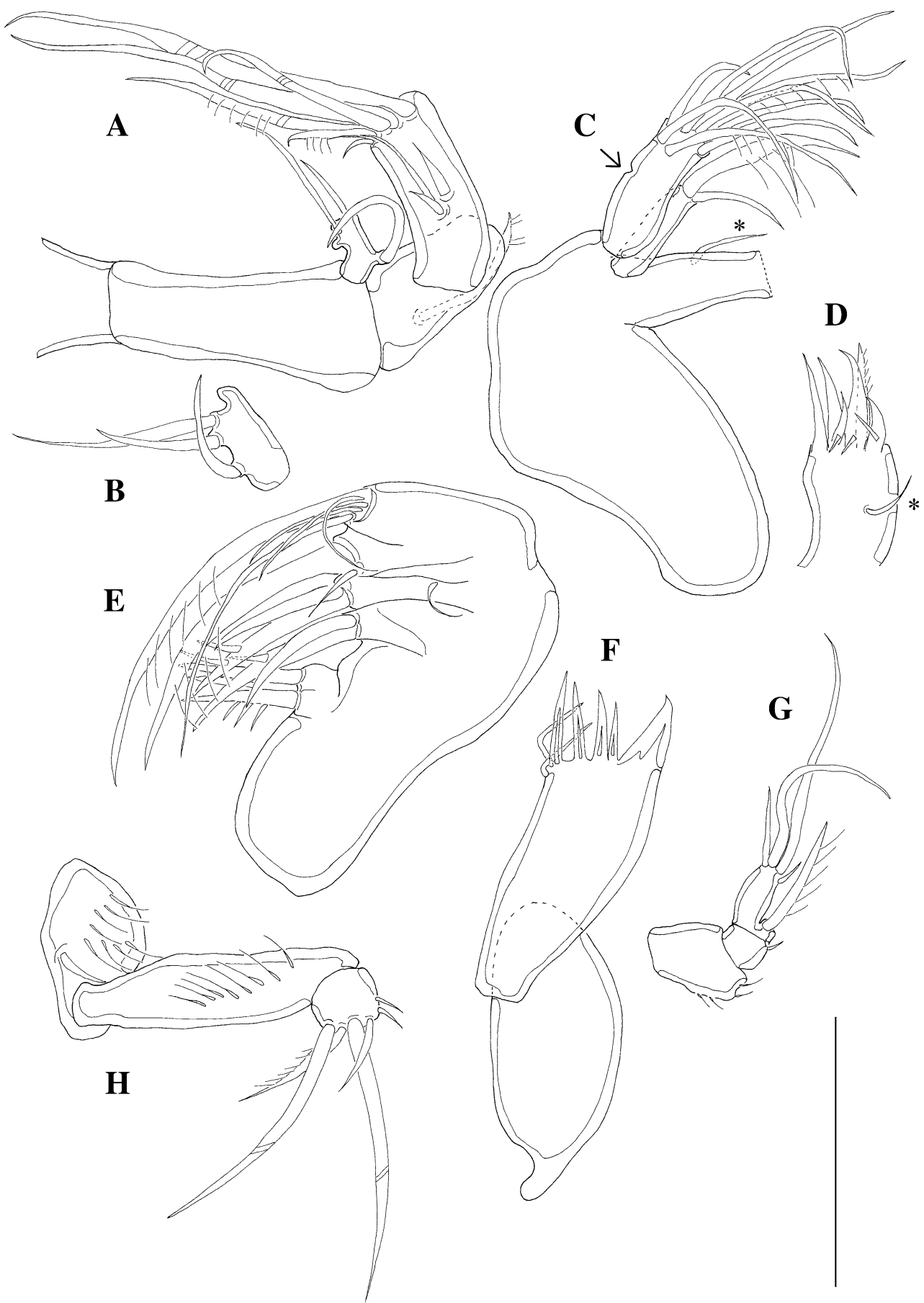

naked setae. Typical position and orientation of maxilla are shown in Fig. 2.

Maxilliped (Fig. 6h). Syncoxa with 2 rows of spinules directed toward 1 slender naked seta near middle of inner margin. Basis with a row of spinules. Enp 1-segmented, with 2 short spinules along outer margin, apically with 2 long, strong, geniculate setae and 2 short setae, one of which is unipinnate.

Swimming legs (Fig. 7). Armature formula as in Table 2. Thin and elongate intercoxal sclerites present (P1-P4).
Pl (Fig. 7a). Coxa bare. Basis with several outer spinules and 1 very small, outer, naked and 1 inner, plumose seta. Exp slightly longer than enp, both rami 2-segmented. Enp1 without armature, enp2 with 1 inner spinule and 2 terminal slender naked setae, one of which is long. Exp1 with a row of outer spinules and 1 outer unipinnate spine. Exp2 with several outer spinules, 2 outer, unipinnate, spine-like setae and 2 apical, long, unipinnate setae.

P2-P4 (Fig. 7b-d). Coxa of P2-P4 bare. Basis of P2-P4 with 1 outer slender seta (plumose at least in P3 and P4). 
Fig. 7 Wellsopsyllus (W.) antarcticus sp. n., female paratype 2. a $\mathrm{P} 1 ; \mathbf{b} \mathrm{P} 2 ; \mathbf{c} \mathrm{P} 3$ with intercoxal sclerite; $\mathbf{d}$ P4. Scale bar $=0.05 \mathrm{~mm}$

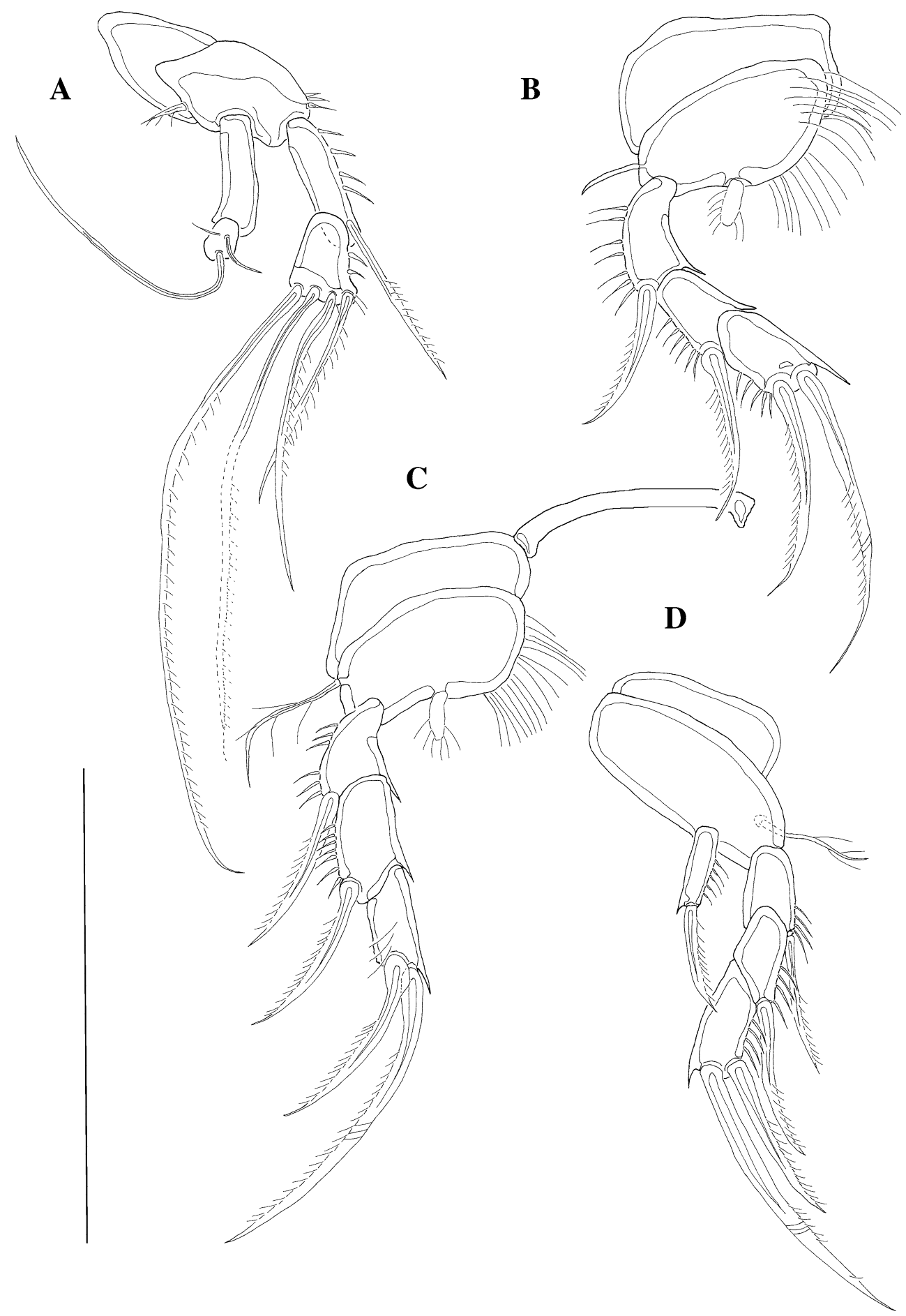

Table 2 Seta and spine formulae of swimming legs of Wellsopsyllus (W.) antarcticus sp. $\mathrm{n}$

\begin{tabular}{llll}
\hline & Basis & Exopod & Endopod \\
\hline P1 & $1-0$ & 0.022 & 0.020 \\
P2 & $0-1$ & 0.0 .011 & 000 \\
P3 & $0-1$ & 0.0 .011 & 000 \\
P4 & $0-1$ & 0.0 .011 & 010 \\
\hline
\end{tabular}

Basis of P2 and P3 with many very long, thin setules along inner margin. 3-segmented exps with rows of spinules along outer margin. Inner distal corners of exps 1-3 drawn into unguiform projections of different sizes. Exp1 and $\exp 2$ with 1 outer, stout, unipinnate spine. Exp3 with 1 outer, stout, unipinnate spine and 1 apical, long, geniculate, unipinnate spine-like seta. Exp3 of P3 with a row of thin setules. Enp of P2 and P3 very small, 1-segmented with 
several setules and without setae, exp six times as long as enp. Enp of P4 1-segmented, exp three times as long as enp. Enp1 with a row of spinules at outer margin and 1 strong, unipinnate spine distally.

P5 (Fig. 8c). Legs fused in the middle forming a large plate. Small exp clearly separated from benp. Benp bearing outer basal plumose seta and 1 pinnate seta on the drawn out endopodal part. Exp 1-segmented with 2 naked setae.
Genital complex and P6 (Fig. 8d). Sixth pair of legs represented by small fused outgrowth bearing 2 naked setae on either side of the body.

Male paratype (allotype)

Habitus (Fig. 9). As in female except for separated second and third urosomites. Total body length measured from anterior tip of rostrum to posterior margin of
Fig. 8 Wellsopsyllus (W.) antarcticus sp. n. a Male P5 [paratype 1 (allotype)]; b male P6 [paratype 1 (allotype)]; c female P5 (holotype); d female P6 (paratype 2); arrows indicate positions of lacking setae. Scale bar $=0.02 \mathrm{~mm}$
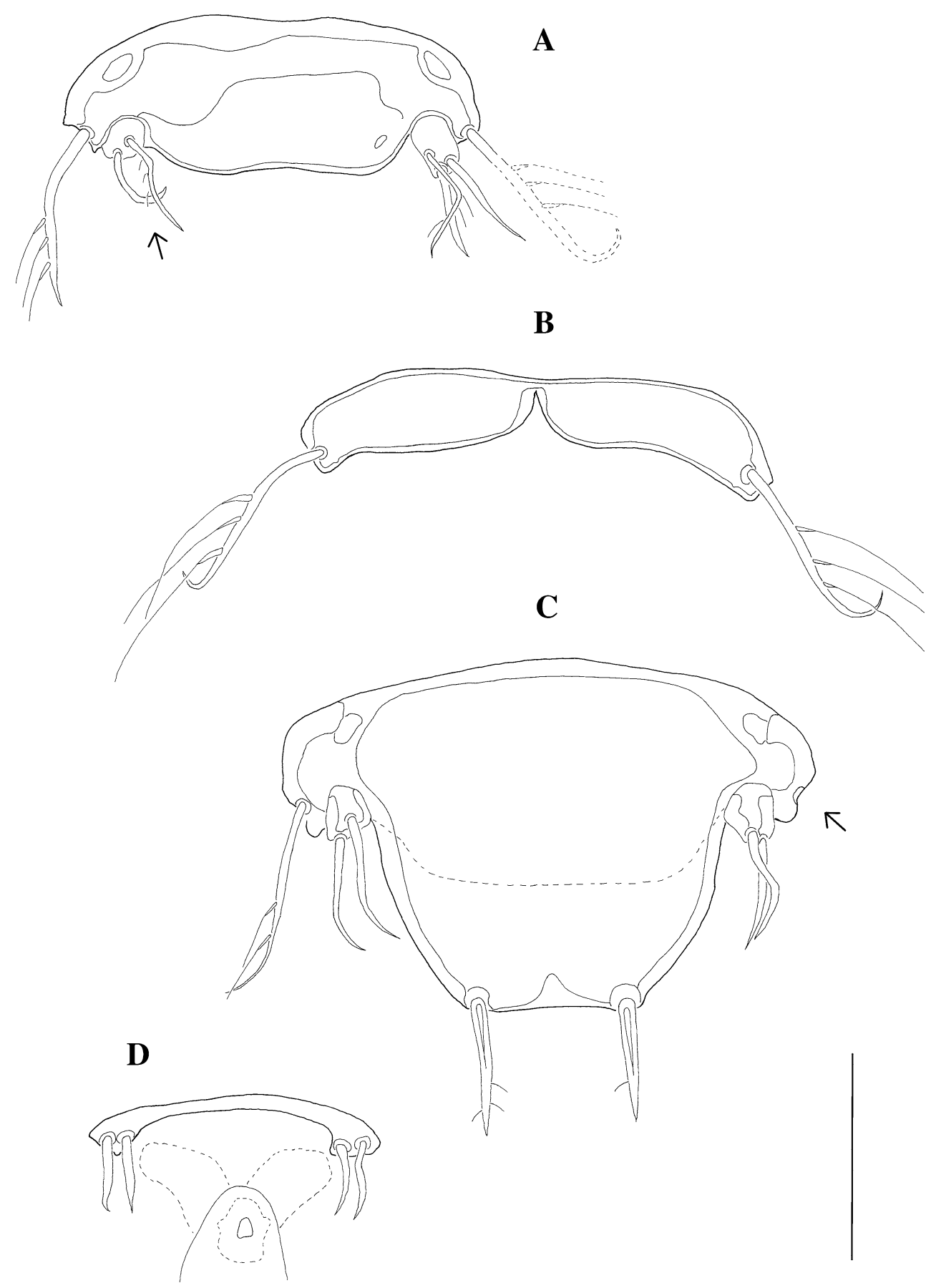
Fig. 9 Wellsopsyllus (W.) antarcticus $\mathrm{sp}$. n., male paratype 1 (allotype)]. a Habitus, dorsal view; b habitus, lateral view. Scale bar $=0.1 \mathrm{~mm}$

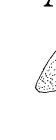

A
B
3

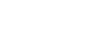

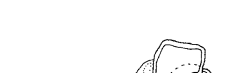

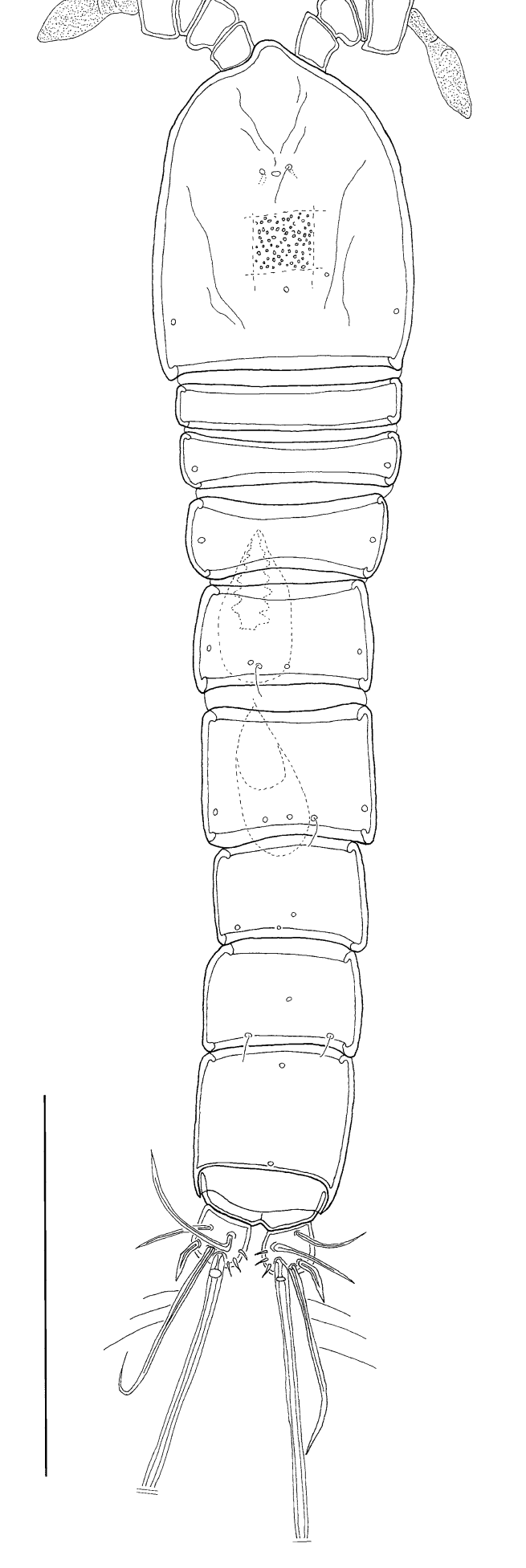

telson: paratype 1 (allotype), $0.301 \mathrm{~mm}$, other specimens, $0.243-0.297 \mathrm{~mm}$; including the furcal rami: paratype $1,0.321 \mathrm{~mm}$, other specimens, $0.263-0.311$ $\mathrm{mm}$.
Spermatophores situated between third and fifth free body somites (Figs. 1 and 9). Furcal rami of adult male (Fig. 4a) short and cylindrical, only slightly as wide as long, with 5 setae and several small spinules along inner 
Fig. 10 Wellsopsyllus (W.) antarcticus $\mathrm{sp} . \mathrm{n}$., male antennula [paratype 1 (allotype)]. a Anterior setation of segments I-IV; $\mathbf{b}$ posterior setation of segments I-IV, position of segment $\mathrm{V}$ indicated by dashed line; $\mathbf{c}$ setation of segment V. Scale bar $=0.02 \mathrm{~mm}$

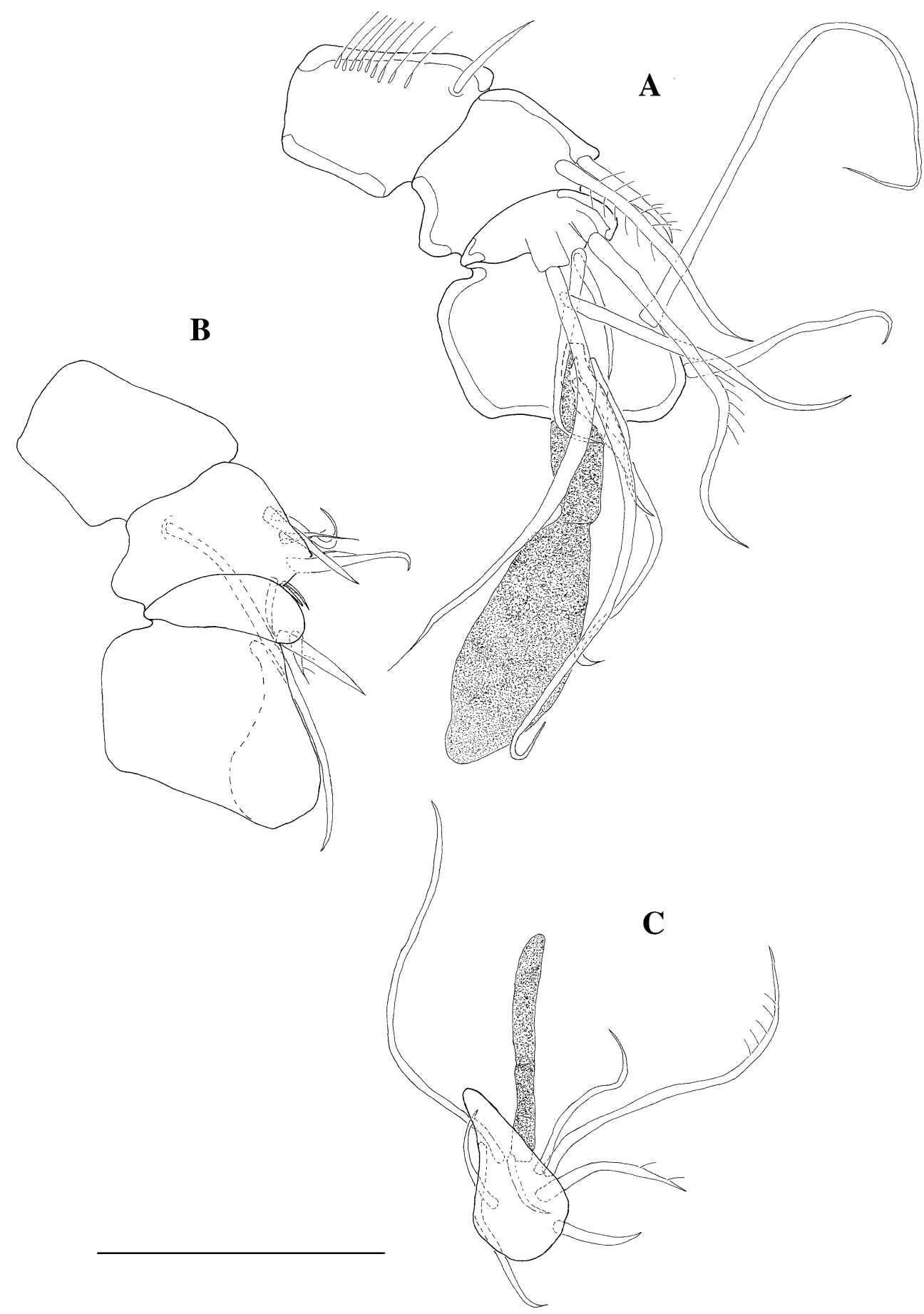

and terminal margin: Seta I absent; seta II slender, dorsally displaced; seta III slender, situated dorsolaterally; seta IV and V dorsally displaced, long and slender; seta IV spinulose along the outer margin (proximal spinules very long); seta $\mathrm{V}$ twice as long as seta IV, with minute spinules at the end of the proximal third; seta VI absent; seta VII slender, plumose, on inner dorsal surface of furcal rami.

Antennule (Fig. 10). Five-segmented, segment I with row of long spinules along inner margin. Armature formula:
I (1): 1 slender naked seta; II (11): 3 slender pinnate setae, one of which with 1 pinnule, 8 slender naked setae of different sizes; III (6): 2 unipinnate setae, one of which is very short, 4 slender naked setae of different sizes, one of which is situated on a small protrusion; IV $(4+(1+$ aes $))$ : 5 slender naked setae of different sizes, one of which is fused at base with aesthetasc; $\mathrm{V}(8+$ aes $)$ : 2 slender unipinnate setae, 6 slender naked setae of different sizes and 1 aesthetasc. 
P5 (Fig. 8a). Legs fused in the middle, exp clearly separated from benp. Benp bearing an outer basal plumose seta and 1 anterior pore (not visible on right side of P5). Exp 1-segmented with 3 setae, the innermost of which pinnate. Exp of right side of body only with 2 setae indicating variability as no notch or insertion point of broken seta visible.

P6 (Fig. 8b). Sixth leg represented by delicate plates, touching in the middle, with 1 outer plumose seta, each. The two plates show a slightly asymmetric shape.

\section{Distribution range}

During the ANDEEP II cruise, Wellsopsyllus (W.) antarcticus sp. $\mathrm{n}$. was found at two stations in the western Weddell Sea (PS61/132, PS61/133; 4 individuals) and one station in the Weddell Abyssal Plain (PS61/138; 5 individuals). One additional specimen was collected during the CROZEX expedition at an abyssal station (15775 M6 C9) south of the Crozet Isles in the Indian Ocean (Fig. 1; Table 1). In total, 10 individuals of the new species were obtained from different depths ranging from $1,107 \mathrm{~m}$ in the western Weddell Sea to $\sim 4,540 \mathrm{~m}$ in the Weddell Abyssal Plain and at a depth of 4,202 m south of the Crozet Isles.

\section{Discussion}

Systematics

History of the genus Wellsopsyllus Kunz, 1981

Kunz (1962) revised the Paramesochridae and introduced the new genera Scottopsyllus Kunz, 1962 and Intermedopsyllus Kunz, 1962. Later, Kunz (1981) combined the two genera and presented Scottopsyllus with three subgenera: Scottopsyllus, Intermedopsyllus and the newly established Wellsopsyllus Kunz, 1981.

The genus group name Scottopsyllus as proposed by Kunz (1962), was declared as unavailable (nomen nudum) by Huys (2009) because he found "no trace of a type fixation in the original publication". Huys (2009) therefore replaced the name Scottopsyllus by the next oldest available name from among its synonyms, Wellsopsyllus Kunz, 1981. He found the same problem of lacking type fixation for the subgenus Intermedopsyllus.

In the course of his nomenclatorical revision, Huys (2009) renamed the subgenera Scottopsyllus Apostolov and Marinov, 1988 and Intermediopsyllus Huys, 2009 (and introduced the new spelling Intermediopsyllus instead of Intermedopsyllus). At present, the genus Wellsopsyllus contains 15 species (including the new species herein presented). The subgenus Wellsopsyllus Kunz, 1981 was conserved and contains 4 species to date, including the deep-sea species Wellsopsyllus (W.) abyssalis (Becker, 1979) and Wellsopsyllus (W.) antarcticus sp. n.

\section{Characteristics of the genus and its subgenera}

Following Kunz's (1981) diagnosis of the genus Scottopsyllus and based on the course of action by Huys (2009), the genus Wellsopsyllus is characterized by the elongate and vermiform body shape, a small rostrum, the 1-segmented exp of the antenna, exp of mandibular palp 1- or 2-segmented, the 3-segmented exps of P2 and P3, the exp of P4 2- or 3-segmented, the presence of 2 setae (spines) at the distal segment of the exps of P2-P4, the 1-segmented enps of $\mathrm{P} 2$ and $\mathrm{P} 3$ with or without 1 very small seta, and the 1- or 2-segmented enp of P4 with 1 seta. Veit-Köhler (2000) added that the enps of P2 and P3 can be described as "paramecium"-shaped.

The main diagnostic character of the subgenus Wellsopsyllus is the 1-segmented enp of $\mathrm{P} 4$. The subgenus Scottopsyllus is characterized by a 2-segmented enp of $\mathrm{P} 4$, while the subgenus Intermediopsyllus shows a 2-segmented exp of P4 due to the fusion of the 2 proximal segments [Kunz 1981; see Table 2 in Veit-Köhler (2000)].

Allocation of Wellsopsyllus (W.) antarcticus sp. $n$. and differentiation from congeners

The new species is placed into the genus Wellsopsyllus and therein into the subgenus Wellsopsyllus as Wellsopsyllus (W.) antarcticus $\mathrm{sp}$. $\mathrm{n}$. The new species shows the genus characteristics such as the vermiform body shape, the 1-segmented exp of the antenna, the 3-segmented exps on $\mathrm{P} 2$ and $\mathrm{P} 3$, and the presence of 2 setae at the distal segments of the P2-P4 exps. The 1-segmented enp on P2 and $\mathrm{P} 3$ is present, but very small compared to most other species of the genus. The presence of a 3-segmented exp and a 1-segmented enp of $\mathrm{P} 4$ are the determining characters for placing the species in the subgenus Wellsopsyllus.

Wellsopsyllus (W.) antarcticus sp. n. can be distinguished from the other species of its genus (congeners) and species of its subgenus by the following features:

(1) the small body length $(0.334-0.349 \mathrm{~mm}$ in the female, $0.263-0.321 \mathrm{~mm}$ in the male including the furcal rami) [for sizes of congeners see Table 3 in Veit-Köhler (2000)], the three other species belonging to Wellsopsyllus (Wellsopsyllus) measure between $0.38 \mathrm{~mm}$ and $0.95 \mathrm{~mm}$; (2) very small furcal rami (mostly much longer than broad in its congeners); (3) a reduced mandibular palp and maxillula, characteristics that do not appear in other species of the subgenus; (4) the presence of 2 setae on the distal segment of enp of P1 [according to the original subgenus diagnosis by Kunz (1981), there is only 1 seta]; 
(5) the shape and very small size of the enp of P2 and P3 are different from other species of the subgenus; (6) the shape and armature of female and male P5 and P6 are distinguishable from the congeners.

The presence of very small furcal rami and the minute enps of P2 and P3 suggests a closer relationship with the genus Leptopsyllus T. Scott, 1894. However, this genus is mainly characterized by the complete absence of enps in P2 and mostly in P3. The new species seems to not really belong to either of the two genera, casting doubts about its present classification, being evident the need of a detailed revision of the genus. As Kunz (1992) points out, there is a remarkable resemblance between a group of three species across both genera: Wellsopsyllus (Intermediopsyllus) smirnovi (Kunz, 1992) [incertae sedis according to Wells (2007)], Leptopsyllus (Leptopsyllus) platyspinosus Mielke, 1984 and Wellsopsyllus (Intermediopsyllus) minutus (Nicholls, 1939). Kunz (1992) stated that these species may possibly be delimitated in a phylogenetically connected group. The lack of adequate descriptions of the mouthparts in previous species descriptions, however, withheld him from this step. Wellsopsyllus (W.) antarcticus sp. n. shows strong connections to these species.

Wellsopsyllus (I.) smirnovi and W. (I.) minutus have very small enps, which are very similar to those of the new species. Since the subgenus Intermediopsyllus is differentiated from the subgenus Wellsopsyllus by a 2 -segmented exp of P4, the new species with a 3-segmented exp of P4 cannot be placed there.

In comparison with the other species of their respective genus, W. (W.) antarcticus sp. n., W. (I.) smirnovi and $L$. (L.) platyspinosus show a marked reduction of the mandibular palp (see Kunz 1992). Furthermore, W. (W.) antarcticus sp. n., W. (I.) minutus and $L$. (L.) platyspinosus show a reduced maxillula bearing neither enp nor exp. In addition, $L$. (L.) platyspinosus and $W$. (I.) smirnovi conform in the structure of the maxilla, with proximal and middle endites reduced in both species.

The similarities between the three formerly described species and the new species presented here confirm our impression of an urgent need to revise the genera in question. At present, the classification is mainly based on the segmentation of the swimming legs, but there are other important characteristics to be considered (e.g., mouthparts, furcal rami). For now, the new species will be placed in Wellsopsyllus (Wellsopsyllus), but we strongly recommend a complete revision of the genera. This is, however, beyond the scope of this paper.

Habitat and body size

According to Herring (2003), continental slopes and depths below $200 \mathrm{~m}$ belong to the deep sea. Besides $W(W$.) antarcticus sp. n., the genus contains only two other described deep-sea species, namely Wellsopsyllus (W.) abyssalis (Becker, 1979) and Wellsopsyllus (I.) antoniae (Plum and George, 2009). The latter species has been collected from the plateau and the slope of the Great Meteor Seamount (Atlantic Ocean) at depths between 297 and $455 \mathrm{~m}$. The sea floor in the sampling area is covered with coarse biogenic sediment composed of fragments of mollusk shells and corals (Gad and Schminke 2004). Wellsopsyllus (W.) abyssalis was collected in the Peru Trench (Pacific Ocean) at a depth of 5,000 m (Becker 1972). The sediment was described as a hemipelagic soft sediment of largely terrigenous origin with abundant detritus (Becker 1972).

Muddy sediments do not have an interstitial habitat, but the mud exists in two distinct horizontal layers: an upper fluid layer overlying more compacted and firm mud beneath. Generally spoken, large and vermiform species may be strong enough to burrow in fine sediment (Warwick 1984). For organisms burrowing only in the upper fluid mud layer, however, Schwinghamer (1981) found no restriction in size. Therefore, different size classes of burrowing meiobenthic copepods may be present in muddy sediments.

From the genus Wellsopsyllus, only the largest three species with a body length of $0.8-0.95 \mathrm{~mm}$ were known to inhabit deep-sea and shallow-water muddy sediments: Wellsopsyllus (W.) abyssalis (Becker, 1979), Wellsopsyllus (W.) gigas (Wells, 1965) and Wellsopsyllus (S.) praecipuus (Veit-Köhler, 2000). All known smaller species of Wellsopsyllus (maximum body length $0.65 \mathrm{~mm}$ ) seemed to be restricted to areas with coarser sediments (Veit-Köhler 2000; Plum and George 2009). With a maximum body size of $0.349 \mathrm{~mm}$, Wellsopsyllus (W.) antarcticus sp. $\mathrm{n}$. is among the smallest species of the genus. It is the first Wellsopsyllus species of its size class found to be living in the muddy, fluidly textured upper centimeters of deep-sea sediments. Other very small species of Paramesochridae (e.g., Emertonia andeep, E. diva, Emertonia schminkei Veit-Köhler and Drewes, 2009) recently described from muddy deep-sea sediment confirm this finding.

Biogeography and individual density

Our knowledge about geographic ranges of harpacticoid copepod species in the deep sea has recently grown considerably. The great amount of material obtained, for example, during the DIVA, ANDEEP and CROZEX expeditions carried out during the international CeDAMar program provided the first opportunities for biogeographical studies of benthic deep-sea copepods (Gheerardyn and Veit-Köhler 2009; Menzel 2011; Menzel et al. 2011). 
Regarding abyssal depths, the genus Wellsopsyllus was only reported from the Pacific Ocean (Becker 1979) and the Scotia Sea (Gheerardyn and Veit-Köhler 2009) so far. The new species presented here was first assigned to Leptopsyllus $[L$. sp. 2 in Gheerardyn and Veit-Köhler (2009)] because of its questionable systematic position due to the minute enps of P2 and P3. With the present contribution, it is evident that the distribution range of the genus Wellsopsyllus in the abyss is much wider.

Nine out of the ten obtained individuals of $W$. (W.) antarcticus $\mathrm{sp}$. $\mathrm{n}$. were restricted to the Weddell Sea. The presence of one individual in the Indian Ocean, found at a station located approximately $5,800 \mathrm{~km}(3,130$ sea miles) apart from the type locality, may indicate a wide distribution range of the species. According to the findings of Gheerardyn and Veit-Köhler (2009), certain species of Paramesochridae are widespread and thus must be able to surmount major ridge systems or fracture zones that may be obstacles for many other deep-sea species. The relatively homogenous depth profile between the two regions where $W$. (W.) antarcticus sp. n. was found shows none of these geographic features (Fig. 1). However, without evidence for a continuous distribution between the Weddell Sea and the Indian Ocean, to date the possibility of a disjunct distribution has to be kept in mind.

In any case, it is astonishing that no individual of $W$. (W.) antarcticus sp. n. was found in the Scotia Sea adjacent to the western Weddell Sea. Despite the geographic closeness, the two paramesochrid species collected in the Scotia Sea during the ANDEEP I expedition belonged to the group of more typical Wellsopsyllus species, with welldeveloped "paramecium"-shaped enps (Gheerardyn and Veit-Köhler 2009).

From the ANDEEP II cruise to the Weddell Sea, MUC cores from five stations were made available to us. The number of adult Paramesochridae per core varied between 0 and 2 individuals (maximum density 0.78 ind. $10 \mathrm{~cm}^{-2}$ ). Three of the stations (PS61/132, PS61/133 and PS61/138; Fig. 1) revealed in total 18 adult Paramesochridae belonging to five different species (Gheerardyn and VeitKöhler 2009). Nine out of these 18 individuals belonged to $W$. (W.) antarcticus sp. $\mathrm{n}$. Considering the low individual numbers of the other species, $W$. (W.) antarcticus sp. n. can be referred to as the dominant paramesochrid species in this area. Nevertheless, further sampling is necessary in order to confirm its dominance within the Paramesochridae in the Weddell Sea.

The number of all copepods (adult copepods and copepodids) with 2,669 specimens obtained from the investigated five stations shows, however, the small contribution that Paramesochridae make to the whole meiofaunal copepod community in the deep sea. Nevertheless, their low densities, ubiquity and relatively easy identification, made Gheerardyn and Veit-Köhler (2009) consider the Paramesochridae as an appropriate group to base investigations of the biogeography of deep-sea harpacticoid copepods.

Acknowledgments The authors would like to thank Prof. Dr. Ann Vanreusel, Dr. Ilse De Mesel (Ghent University, Belgium), Prof. Dr. Andrew Gooday (National Oceanography Centre, Southampton) and Prof. Dr. Pedro Martínez Arbizu (DZMB, Senckenberg am Meer) for sampling the material on board of the RV Polarstern (ANDEEP I and II). Sample treatment and meiofauna sorting was carried out by Jutta Heitfeld, Annika Hellmann and Marco Bruhn (DZMB). Prof. Dr. David Billet (National Oceanography Centre, Southampton) provided the material from the Benthic CROZEX expedition, and Hanna Hafemann (DZMB) carried out the sample sorting. Dr. Hendrik Gheerardyn (Ghent University) determined the working species of Paramesochridae from the CeDAMar expeditions. The critical comments of Prof. Dr. John B. J. Wells, Dr. Hendrik Gheerardyn and an anonymous reviewer are gratefully acknowledged. This is a contribution to CeDAMar (Census of the Diversity of Abyssal Marine Life), a field project of the Census of Marine Life (CoML) and ANDEEP publication no. 154.

\section{References}

Apostolov A, Marinov TM (1988) Copepoda Harpacticoida. Fauna Bulgarica 18:1-384

Becker KH (1972) Eidonomie und Taxonomie abyssaler Harpacticoidea (Crustacea, Copepoda). Dissertation, Christian-AlbrechtsUniversität Kiel

Becker KH (1979) Eidonomie und Taxonomie abyssaler Harpacticoidea (Crustacea, Copepoda). Teil II. Paramesochridae, Cylindropsyllidae und Cletodidae. Meteor Forsch Ergebn (D) 31:1-37

Brandis D, Allspach A, Menner L, Türkay M (2007) The collection management system SeSam of the Senckenberg Research Institute, Frankfurt a. M., Germany. Zoology 110:161-162

Brandt A, De Broyer C, Gooday AJ, Hilbig B, Thomson MRA (2004) Introduction to ANDEEP (ANtarctic benthic DEEP-sea biodiversity: colonization history and recent community patterns) - a tribute to Howard L. Sanders. Deep-Sea Res II 51:1457-1465. doi:10.1016/j.dsr2.2004.08.006

Diepenbroek M, Grobe H, Sieger R (2000) PanMap. http://www. pangaea.de/Software/PanMap

Drzycimski I (1967) Zwei neue Harpacticoida (Copepoda) aus dem norwegischen Küstengebiet. Sarsia 30:75-82

Gad G, Schminke HK (2004) How important are seamounts for the dispersal of interstitial meiofauna? Arch Fish Mar Res 51(1-3): 43-54

Gheerardyn H, Veit-Köhler G (2009) Diversity and large-scale biogeography of Paramesochridae (Copepoda, Harpacticoida) in South Atlantic abyssal plains and the deep Southern Ocean. Deep-Sea Res I 56(10):1804-1815. doi:10.1016/j.dsr.2009. 05.002

Gutzmann E, Martínez Arbizu P, Rose A, Veit-Köhler G (2004) Meiofauna communities along an abyssal depth gradient in the Drake Passage. Deep-Sea Res II 51(14-16):1617-1628. doi: 10.1016/j.dsr2.2004.06.026

Herring P (2003) The biology of the deep ocean. Oxford University Press, Oxford, p 324

Huys R (1987) Paramesochra T. Scott, 1892 (Copepoda, Harpacticoida): a revised key, including a new species from the SW Dutch coast and some remarks on the phylogeny of the Paramesochridae. Hydrobiologia 144:193-210 
Huys R (2009) Unresolved cases of type fixation, synonymy and homonymy in harpacticoid copepod nomenclature (Crustacea: Copepoda). Zootaxa 2183:1-99

IOC, IHO, BODC (1994) GEBCO Digital Atlas, published on behalf of the intergovernmental oceanographic commission (of UNESCO) and the International Hydrographic Organization as part of the General Bathymetric Chart of the Oceans (GEBCO). British Oceanographic Data Center, Birkenhead

Kunz H (1962) Revision der Paramesochridae (Crustacea Copepoda). Kieler Meeresforsch 18(2):245-257

Kunz H (1981) Beitrag zur Systematik der Paramesochridae (Copepoda, Harpacticoida) mit Beschreibung einiger neuer Arten. Mitt Zool Mus Univ Kiel I(8):2-33

Kunz H (1992) Beitrag zur Kenntnis mariner Copepoda Harpacticoida (Fam. Paramesochridae Lang) mit Beschreibung zweier neuer Arten und einer neuen Unterart. Crustaceana 62(1):85-97

Lang K (1936) Copepoda Hartpacticoida. In: Bock S (ed.) Further results of the Swedish Antarctic Expedition 1901-1903, vol 3. Stockholm, pp 1-68

Lang K (1944) Monographie der Harpacticiden (Vorläufige Mitteilung). Almqvist \& Wiksells Boktryckeri Ab, Uppsala, p 39

Lang K (1948) Monographie der Harpacticiden I und II. Reprint Otto Koeltz Science Publication, Königstein, p 1682

Martínez Arbizu P, Brix S (2008) Editorial: bringing light into deepsea biodiversity. Zootaxa 1866:5-6

Menzel L (2011) First descriptions of copepodid stages, sexual dimorphism and intraspecific variability of Mesocletodes Sars, 1909 (Copepoda, Harpacticoida, Argestidae), including the description of a new species with broad abyssal distribution. ZooKeys 96:39-80. doi:10.3897/zookeys.96.1496

Menzel L, George KH, Martínez Arbizu P (2011) Submarine ridges do not prevent large-scale dispersal of abyssal fauna: a case study of Mesocletodes (Crustacea, Copepoda, Harpacticoida). Deep-Sea Res I 58:839-864. doi:10.1016/j.dsr.2011.05.008

Michels J, Büntzow M (2010) Assessment of Congo red as a fluorescence marker for the exoskeleton of small crustaceans and the cuticle of polychaetes. J Microsc 238(2):95-101. doi: 10.1111/j.1365-2818.2009.03360.x

Mielke W (1984) Interstitielle Fauna von Galapagos. XXXI. Paramesochridae (Harpacticoida). Mikrofauna Meeresb 1:63-147

NGDC/NOAA (1993) Global relief data on CD-ROM. World Data Center for Marine Geology \& Geophysics, Boulder, Courtesy Defense Mapping Agency

Nicholls AG (1939) Some new sand-dwelling copepods. J Mar Biol Assoc UK 23:327-341

Plum C, George KH (2009) The paramesochrid fauna of the Great Meteor Seamount (Northeast Atlantic) including the description of a new species of Scottopsyllus (Intermedopsyllus) Kunz (Copepoda: Harpacticoida: Paramesochridae). M. Mar Biodiv 39:265-289. doi:10.2007/s12526-009-0022-7
Pollard R, Sanders R, Lucas M, Statham P (2007) The Crozet natural iron bloom and export experiment (CROZEX). Deep-Sea Res II 54:1905-1914

Sars GO (1903) Copepoda Harpacticoida. Parts I \& II, Misophriidae, Longipediidae, Cerviniidae, Ectinosomidae (part). An account of the Crustacea of Norway, with short descriptions and figures of all the species $5: 1-28+$ pls. $1-16$

Schwinghamer P (1981) Characteristic size distributions of integral benthic communities. Can J Fish Aquat Sci 38:1255-1263

Scott T (1894) Additions to the fauna of the firth of forth. Part VI. Reports of the Fishery Board for Scotland, Edinburgh 12(3): 231-271

Vasconcelos DM, Veit-Köhler G, Drewes J, Santos PJP (2009) First record of the genus Kliopsyllus Kunz, 1962 (Copepoda, Harpacticoida, Paramesochridae) from Northeastern Brazil with description of the deep-sea species Kliopsyllus minor sp. nov. Zootaxa 2096:327-337. http://www.mapress.com/zootaxa/2009/ f/zt02096p337.pdf

Veit-Köhler G (2000) Habitat preference and sexual dimorphism in species of Scottopsyllus (Copepoda, Harpacticoida) with the description of Scottopsyllus (S.) praecipuus sp. n. from the Antarctic. Vie Milieu 50(1):1-17

Veit-Köhler G (2004) Kliopsyllus andeep sp. n. (Copepoda: Harpacticoida) from the Antarctic deep sea-a copepod closely related to certain shallow-water species. Deep-Sea Res II 51(14-16): 1629-1641. doi:10.1016/j.dsr2.2004.06.027

Veit-Köhler G (2005) First deep-sea record of the genus Kliopsyllus Kunz, 1962 (Copepoda: Harpacticoida) with the description of Kliopsyllus diva sp $\mathrm{n}$ - the most abundant member of Paramesochridae at two different sites of the Angola Basin. Org Divers Evol 5(Suppl. 1):29-41. doi:10.1016/j.ode.2004.10.003

Veit-Köhler G, Drewes J (2009) Kliopsyllus schminkei sp. n. (Copepoda, Harpacticoida, Paramesochridae)—a new copepod from the southeast Atlantic deep sea (Angola Basin). Zootaxa 2096:313-326. http://www.mapress.com/zootaxa/2009/f/zt0209 6p326.pdf

Warwick RM (1984) Species size distributions in marine benthic communities. Oecologia 61:32-41

Wells JBJ (1965) Copepoda (Crustacea) from the meiobenthos of some Scottish marine sub-littoral muds. P Roy Soc Edinb B 69(1):1-33

Wells JBJ (2007) An annotated checklist and keys to the species of Copepoda Harpacticoida (Crustacea). Zootaxa 1568:1-872

Wolff GA, Billett DSM, Bett BJ, Holtvoeth J, FitzGeorge-Balfour T, Fisher EH, Cross I, Shannon R, Salter I, Boorman B, King NJ, Jamieson A (2011) The effects of natural iron fertilisation on deep-sea ecology: the Crozet Plateau, Southern Indian Ocean. PLoS ONE 6(6):e20697. doi:10.1371/journal.pone.0020697 